\title{
Kalkınma Odaklı Mekânsal Tasarım ve Uygulama Girişimlerinin Sürdürülebilirliğinin Değerlendirilmesi: Sakin Şehir Uzundere Örneğinde Bir Çalışma
}

\author{
Mustafa ÖZGERİ̧ ${ }^{1 *}$, Faris KARAHAN ${ }^{1}$ \\ ${ }^{1}$ Atatürk Üniversitesi, Mimarlık ve Tasarım Fakültesi, Peyzaj Mimarlığı Bölümü, 25240, ERZURUM
}

Öz

Bu çalışma bir turizm merkezi ve aynı zamanda Sakin Şehir (Cittaslow) olan Uzundere'deki yerel kalkınma odaklı mekânsal tasarım ve uygulama çalışmaları ile sosyo-ekonomik, kültürel ve sanatsal faaliyet ve programlar üzerinde yürütülmüştür. Çalışmanın amacı gerek turizmle ilişkili gerekse de turizmden bağımsız olarak, devam eden ve/veya tamamlanan kalkınma odaklı girişimlerin sürdürülebilirliğini değerlendirmektir. Çalışma kapsamında odak grup, yerel halk grubu ve ziyaretçi grubu olmak üzere üç farklı grupla anket yapılmıştır. Anketler ANOVA ve T-Testi yapılarak analiz edilmiştir ve katılımcı grupların verdiği cevaplar arasındaki farklılıklar tartışılmıştır. Çalışmanın sonucunda özellikle kırsal doku ve kırsal kültürün hakim olduğu turizm alanlarında yapılacak olan mekânsal tasarım ve uygulama çalışmalarında estetik değerlendirme süreçlerinin işletilmesi ve mekânsal tasarım ve uygulama girişimlerinin sürdürülebilirliği için koruma-kullanıma ek olarak faydalanma dengesinin de karşılaması gerektiği vurgulanmaktadır.

Anahtar Kelimeler: Mekânsal tasarım, sakin şehir, sürdürülebilirlik, turizm, Uzundere.

\section{Evaluation of the Sustainability of Development-Oriented Spatial Design and Implementation Initiatives: A Case Study of the Slow City (Cittaslow) Uzundere}

\begin{abstract}
This study has been carried out on local development-oriented spatial design and implementation studies and socioeconomic, cultural and artistic activities and programs in Uzundere, which is a tourism center and also a Cittaslow. The aim of the study is to evaluate the sustainability of ongoing and / or completed development-oriented initiatives, whether related to tourism or independently of tourism. Within the scope of the study, a survey was conducted with three different groups as focus group, local community group and visitor group. The questionnaires were analyzed using ANOVA and T-Test, and differences between the responses of the participating groups were discussed. As a result of the study, it is emphasized that in spatial design and application studies to be carried out in tourism areas where rural texture and rural culture are dominant, it is emphasized that the balance of utilization should be met in addition to protection-use for the operation of aesthetic evaluation processes and the sustainability of spatial design and implementation initiatives.
\end{abstract}

Keywords: Cittaslow, spatial design, sustainability, tourism, Uzundere. 


\section{Giriş}

Kalkınma kavramı genel olarak üretim kalitesinde ve toplumsal yaşam standartlarında iyileşmeler oluşturan ekonomik ortam olarak tanımlanmaktadır (Alkin, 2008). Özellikle II. Dünya Savaşı sonrasında dünya genelinde tarım, sanayi, inşaat, teknoloji, sağlık, turizm gibi pek çok sektörde hızlı bir gelişim gösteren kalkınma girişimleri bazı çevresel problemleri de beraberinde getirerek, doğa ve doğal kaynaklar üzerinde baskı ve tahribat oluşturmuştur (Kaypak, 2011). Bu sonuç, doğa ve doğal kaynakların korunması gerekliliğini doğurmuş ve insanoğlunu bir takım arayışlara yöneltmiştir. Bu arayışlardan biri olarak 1972 yılında Stockholm'de düzenlenen Birleşmiş Milletler (BM) Çevre Konferansı'nda sürdürülebilirlik kavramı gündeme gelmiştir. Sürdürülebilirlik kavramı 20 Mart 1987 tarihinde Norveç Başbakanı Gro Harlem Brundtland'ın başkanlığında Dünya Çevre ve Kalkınma Komisyonu (WCED) tarafından hazırlanan Ortak Geleceğimiz (Brundtland Raporu) adlı raporda, bugünün ihtiyaçlarını gelecek nesillerin de kendi ihtiyaçlarını tehlikeye atmadan karşılamak olarak tanımlanmıştır (UN, 1987; Aksu, 2011).

Sürdürülebilirlik kavramı sürdürülebilir kalkınma, sürdürülebilir turizm, sürdürülebilir şehirler, sürdürülebilir mekânlar gibi birçok kavrama temel oluşturmaktadır. Ancak sürdürülebilirliği temel edinen tüm kavramların hedef noktası sürdürülebilir kalkınmadır. Gürlük (2001)’e göre içinde bulunduğumuz yüzyılın kalkınma modelleri doğa ve doğal kaynakları dikkate almadan geliştirilmiş modellerdir (Tıraş, 2012). Sürdürülebilir kalkınma ise insanı ve çevreyi dikkate alarak doğal, kültürel ve sosyal kaynakların optimum kullanımı temelinde ekonomik faydalar üretmeyi amaçlayan uzun dönemli bir kalkınma modelidir (Beyhan, 2008). Sürdürülebilir kalkınma, kalkınmayı çevre ilişkisini kurarak sağlayan, sosyal, çevresel ve ekonomik olmak üzere üç temel odak noktası bulunan bir kalkınma modeli olarak özetlenebilir.

1992 yılındaki BM Çevre ve Kalkınma Konferansı'nda sürdürülebilir kalkınma tüm insanlığın ortak hedefi olarak belirlenmiştir (UN, 1993). 1 Eylül 2015 tarihinde ise BM Zirvesi'nde 'Sürdürülebilir Kalkınma 2030 Gündemi' için Sürdürülebilir Kalkınma Hedefleri (SKH) kabul edilmiş ve 1 Ocak 2016 tarihi itibariyle yürürlüğge girmiştir. SKH'nin temel amacı dünyanın karşı karşıya olduğu acil çevresel, siyasi ve ekonomik sorunları çözebilecek hedefler oluşturmaktır. SKH'nin açlık, yoksulluk, ekonomi, eğitim, sağlık, çevre, enerji, adalet, barış, karasal ve sucul yaşam ortamlarının korunması, sanayi, altyapı ve şehircilik gibi konuları kapsayan 17 ana hedefi bulunmaktadır (UN, 2015).

Sürdürülebilirlik anlayışının temel oluşturduğu kavramlardan biri de sürdürülebilir turizmdir. Dünya Turizm Örgütü (WTO) sürdürülebilir turizmi; ziyaretçilerin, turizm endüstrisinin, çevrenin ve ev sahibi toplulukların ihtiyaçlarını ele alırken, mevcut ve gelecekteki ekonomik, sosyal ve çevresel etkileri tam olarak dikkate almak olarak tanımlamıştır. Bunun yanında sürdürülebilir turizm ilkelerini oluştururken çevresel kaynakların korunarak kullanılması, tüm paydaşlar için sosyo-ekonomik faydalar sağlanılması ve ev sahibi toplumun kültürel yapısının garanti altına alınması yönlerine atıfta bulunmaktadır (UNEP and WTO, 2005; UNWTO, 2018).

Sürdürülebilir turizm kavramının ortaya çıkışında turizm alanlarında kalkınma odaklı girişimlerin ve kitlesel ziyaretlerin, turizm arzını oluşturan temel unsurlardan biri olan doğal kaynaklar üzerindeki baskı ve tahribatları etkili olmuştur (Özkök ve Gümüş, 2009; Acuner, 2015). Bunun yanında 90'lı y1llardan itibaren turistlerin tercihlerini bozulmamış bir çevreden yana kullanmaya başlaması ve turizm arzını oluşturan çevresel değerlerin korunması gerekliliği ile beraber alternatif turizm türleri ortaya çıkmıştır (Özbey, 2002; Kozak ve Bahçe, 2009; Bahtiyar Karadeniz, 2014). Ortaya çıkan bu alternatif turizm türlerinden biri de Sakin Şehir (Cittaslow) yaklaşımıdır.

Sakin Şehir (Cittaslow), iyi ve kaliteli bir yaşam için kentlerin ortak refahının sağlanması amacıyla yerel çevrenin, gastronomik kaynakların ve yeni teknolojilerin kullanımının gerçekleştirilmesi olarak tanımlanmaktadır (Miele, 2008; Şahin ve Kutlu, 2014). Cittaslow yaklaşımı fast food kültürüne karşı olarak ortaya çıkan 'Slow Food' (yavaş yemek) felsefesine dayanmaktadır ve 15 Ekim 1999 tarihinde İtalya'nın Orvieto kentinde imzalanan 'Yavaş Şehirler Sözleşmesi’ ile kurulmuştur (Karakurt Tosun, 2013).

Sakin Şehir (Cittaslow), 7 ana politika altında 72 kriter ve 3 özel koşuldan oluşan bir üyelik kriterleri listesine sahiptir. Birliğe üyelik için belirlenen özel koşullar nüfusun 50 000'in altında olması, Slow Food felsefesinin devam ettirilmesi ve Slow Food faaliyetlerine destek ve Cittaslow logosunun görünür kılınmasıdır. Cittaslow'un 7 ana politikası çevre; altyapı; kentsel yaşam kalitesi, tarım, turizm, esnaf ve sanatkar, misafirperverlik, farkındalık ve eğitim; sosyal uyum ve ortaklık konularındadır (URL-1, 2020).

Cittaslow birliğine 2020 yılı temmuz ayı itibariyle 30 ülkeden 264 şehir üyedir (URL-2, 2020). Birliğin Türkiye'den ilk üyesi İzmir'in Seferihisar ilçesidir. Türkiye'nin Cittaslow birliğine dahil olan 17 üyesi bulunmaktadir (URL-1, 2020). 
Bu çalışmanın yürütüldüğü, bir turizm merkezi olan ve turizmde Sakin Şehir (Cittaslow) ismiyle markalaşmaya çalışan Erzurum'un Uzundere ilçesinde de çoğunluğu son 15 yılda kamu, yerel yönetim, üniversite ve sivil toplum kuruluşları yürütücülüğü, ortaklığı ve iştiraki ile yerel kalkınmanın bir aracı olarak gerek turizmle ilişkili gerekse de turizmden bağımsız bir çok mekânsal tasarım ve uygulama çalışması ile bazı faaliyetler yürütülmüş ve yürütülmeye de devam edilmektedir. Bununla beraber tamamlanmış ve/veya devam etmekte olan mekânsal tasarım ve uygulama çalışmaları ile diğer faaliyetler ilçenin, turizm arzını oluşturan doğal ve kültürel peyzajını ve sosyal yapısını da dönüştürmekte ve sürdürülebilirlik kavramının sosyal, ekonomik ve çevresel fayda boyutlarıyla ilişkilendirilmesi gerekliliği sonucunu doğurmaktadır. Doğal olarak bu sonuç, ilçede kalkınma odaklı yürütülen mekânsal tasarım ve uygulamalar ile diğer faaliyetlerin 'doğal ve kültürel çevre üzerindeki etkileri ve sosyo-ekonomik katkıları ile bakıldığında sürdürülebilir midir?’ sorusunu gündeme getirmektedir.

Bu duruma yönelik olarak çalışma ile Sakin Şehir Uzundere ilçesinde devam eden ve/veya tamamlanan mekânsal tasarım ve uygulama çalışmaları ile diğer faaliyetlerin sürdürülebilirliğinin ve/veya sürdürülebilirliğe katkısının değerlendirilmesi amaçlanmaktadır.

\section{Materyal ve Metot}

\subsection{Materyal}

Çalışma, Erzurum ili Uzundere ilçesinde yürütülmüştür. Uzundere ilçesinde devam eden ve/veya tamamlanan mekânsal tasarım ve uygulama çalışmaları ile ilçede sosyal, ekonomik, kültürel ve sanatsal olarak yürütülmekte olan faaliyetler çalışmanın ana materyalini oluşturmaktadır. İlçenin peyzaj kaynak değerleri ise çalışmanın yardımcı materyali olarak kullanılmıştır.

Uzundere ilçesi idari olarak Doğu Anadolu Bölgesi'nde bulunan Erzurum iline bağlıdır ve 4042' - 40²6' kuzey enlemleri ile $41^{\circ} 26^{\prime}-41^{\circ} 47^{\prime}$ doğu boylamları arasındadır (Şekil 1). Yüzölçümü $840 \mathrm{~km}^{2}$ olan Uzundere'nin nüfusu 8744'tür. İlçe coğrafi olarak ise Çoruh Havzası'nı oluşturan birçok vadiden biri olan Tortum Çayı Vadisi'nde yer almaktadır. Çoruh Havzası, Uluslararası Doğa Koruma Birliği (IUCN) tarafından sahip olduğu biyolojik çeşitliliği ve hassas türleriyle dünyanın 200 önemli ekolojik bölgesi ve 34 sıcak noktasından biri olarak ilan edilen, Kafkasya Ekolojik Bölgesinin batı bölümünü oluşturmaktadır (CEPF, 2003).

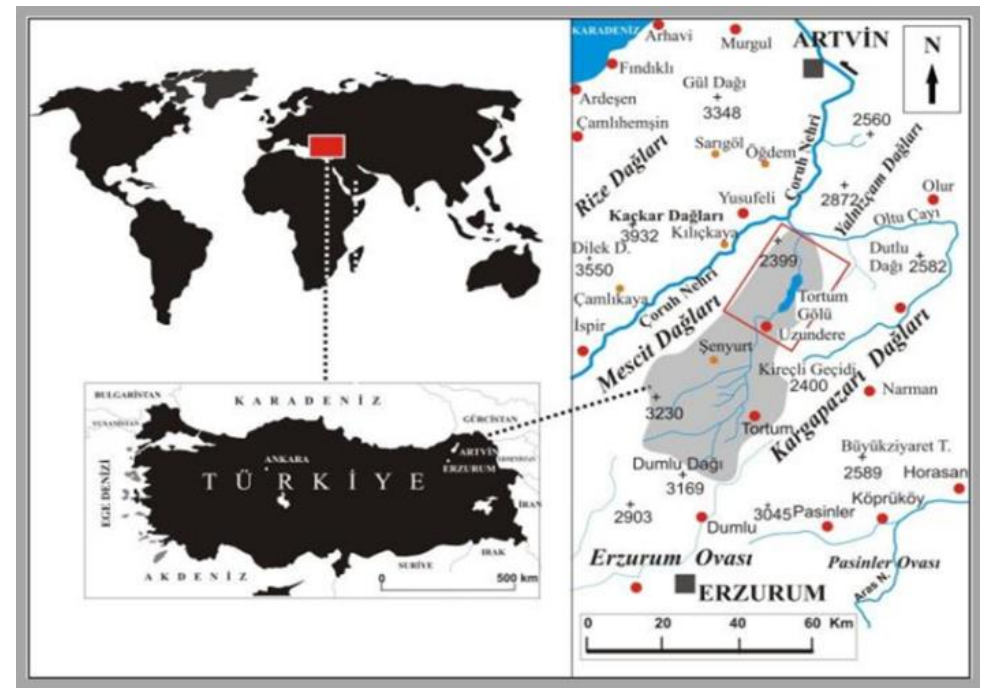

Şekil 1. Uzundere lokasyon haritas1 (Karahan et al. 2011)

Uzundere'nin iklimi, karasal iklim ile Karadeniz iklimi arasında geçiş özelliği göstermektedir ve jeomorfolojik yapısı iklime mikroklima özelliği kazandırmıştır. İlçenin jeomorfolojik yapısını dar ve derin vadi tabanları ile tepelik alanlar oluşturmaktadır ve ilçede çok geniş bir sahayı etkileyen heyelanlar ve toprak kaymaları görülmektedir (Kopar and Çakır, 2013). Uzundere jeolojik olarak ise kalın, birikmiş tortul tabakasının kıvrılma ve kırılma hareketleri sonucunda kıvrımlı bir yapıya sahip olmuştur ve sahada volkanik ve sedimenter kayaç yapısı hakimdir (Atalay, 1979; Kopar ve Sevindi, 2013). İlçenin florasında 22 familyaya ait 41 odunsu ve 48 familyaya ait 286 otsu bitki türü bulunmaktadır ve bunların 44 tanesi endemik bitkidir (EDTMP, 2013). İlçede yerleşik yaşayan kuş türü sayısı 207'dir ve boz ayı (Ursus arctos), çengel boynuzlu dağ keçisi (Rupicapra rupicapra), dağ keçisi (Capra aegagrus), kurt (Canis lupus), yaban kedisi (Felis silvestris), vaşak (Lynx lynx) 
populasyonları ile önemli memeli alanı niteliğindedir (Karahan et al., 2017). Ayrıca ilçede 5 farklı familyaya ait 138 kelebek türü bulunmaktadır. İlçede çeşitli koruma statüleri ile korunan 24 farklı doğal ve kültürel unsur vardır. Ayrıca geleneksel olarak yapılan çeşitli festival ve şenlikler bulunmaktadır. İlçede genel olarak kırsal doku ve kırsal kültür hakimdir ve bu kırsal kültür kendini mimari yapılarda da göstermektedir. İlçe ekonomisinde turizm önemli bir yere sahiptir ve ilçede turizm açısından öneme sahip olan bazı doğal ve kültürel peyzaj kaynak değerleri Şekil 2'de verilmiştir.

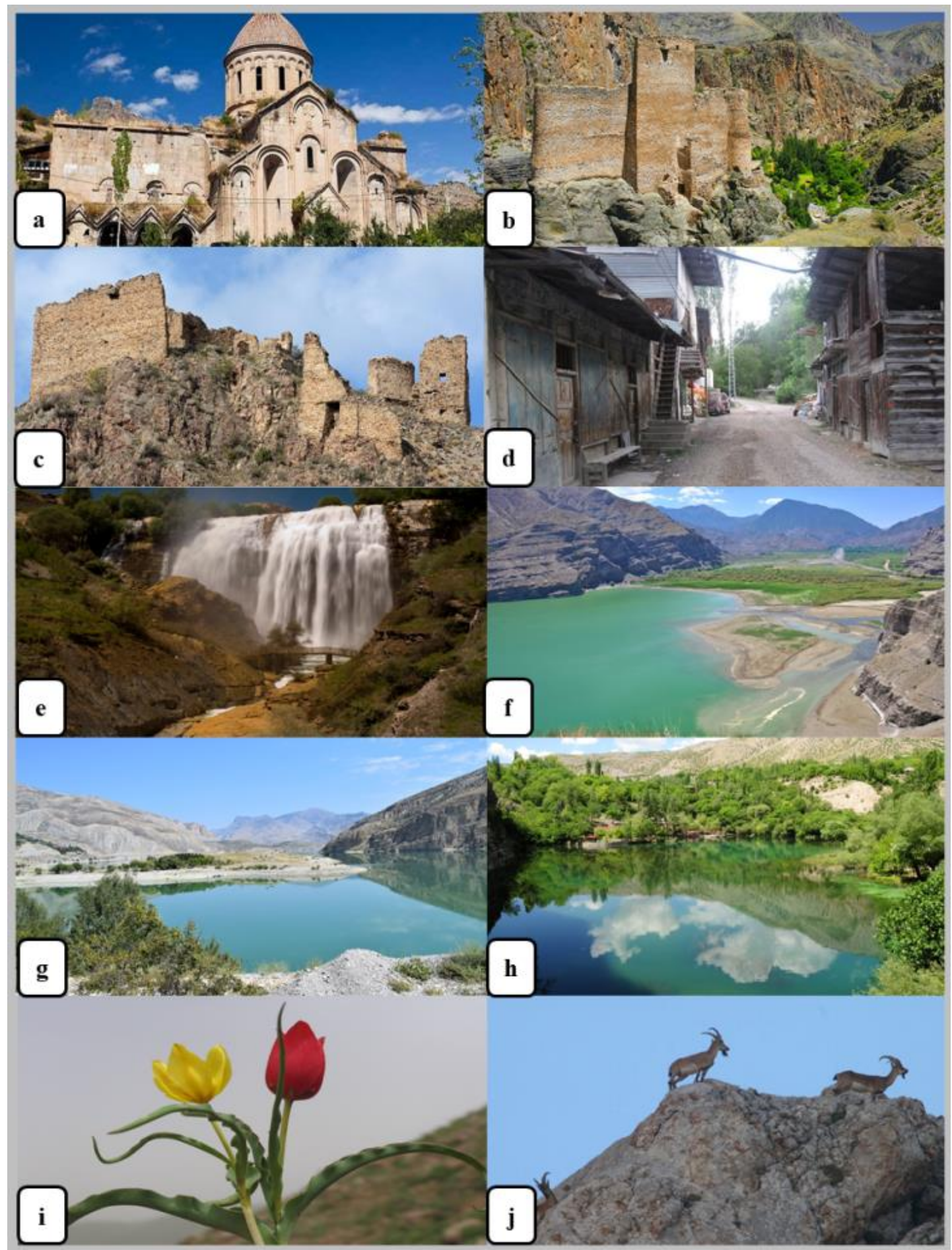

Şekil 2. Uzundere'nin bazı doğal ve kültürel peyzaj kaynak değerleri (a-Öşvank Manastırı b-Engüzekkapı Kalesi cSapaca Kalesi d-Geleneksel mimari örnekleri e-Tortum Şelalesi f-Tortum Gölü g-Uzunburun Yarımadası h-Yıkıklar (Yedigöller) i-Tulipa armena Boiss. var. armena j-Rupicapra rupicapra)

Çalışmanın ana materyalini oluşturan mekânsal tasarım çalışmaları, fiziki uygulamalar ve diğer faaliyetlere ait açıklayıcı bilgiler Tablo 1'de verilmiştir. 
Tablo 1. Uzundere'de yürütülen mekânsal tasarım ve uygulamalar ile diğer faaliyetler

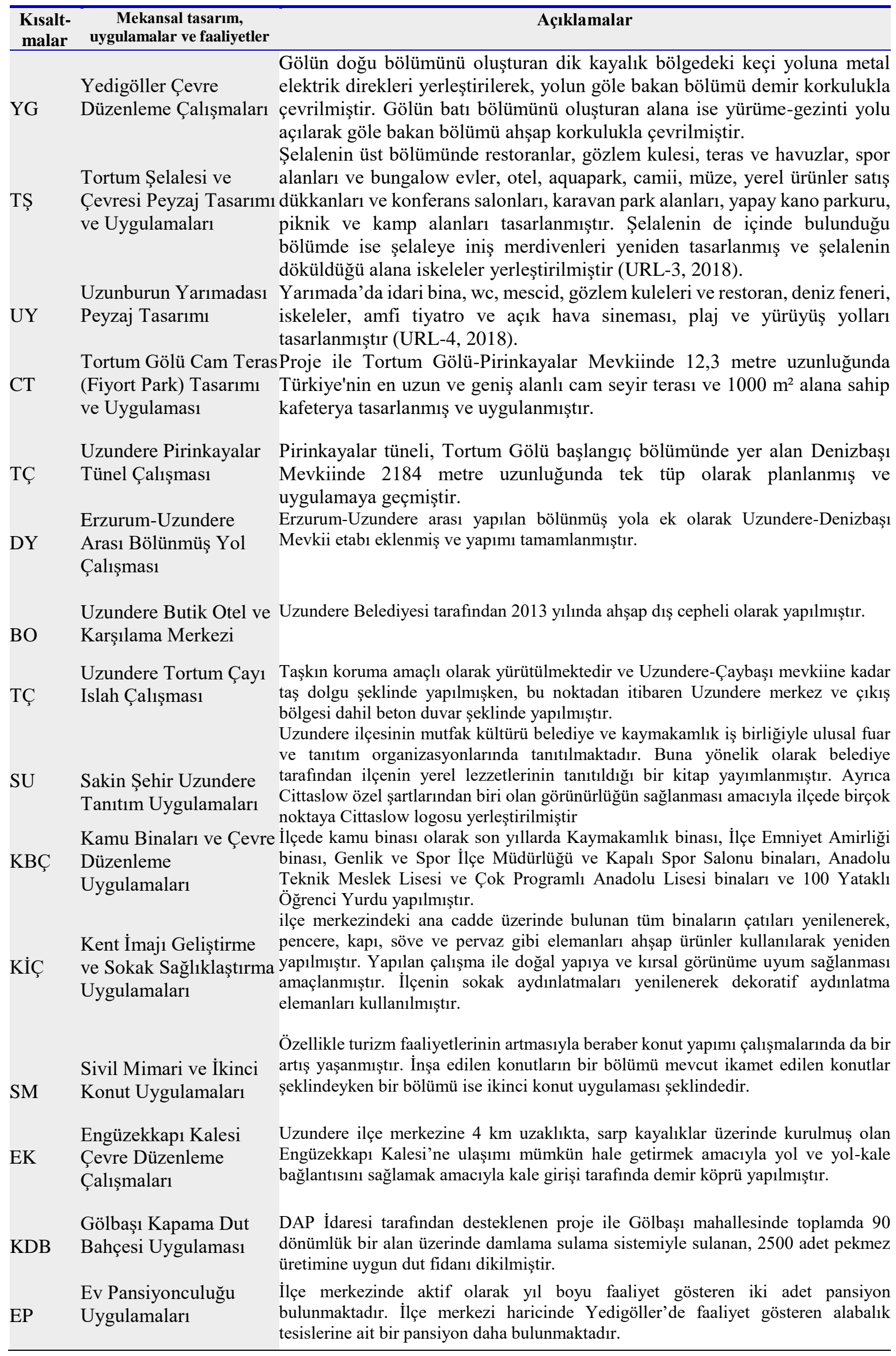


Tablo 1. Tablo devam ediyor

\begin{tabular}{|c|c|c|}
\hline $\mathrm{KG}$ & $\begin{array}{l}\text { Kadın Girişimciliği } \\
\text { (Seramik Atölyesi, } \\
\text { Gastronomi ve } \\
\text { Seracılık) Uygulamaları }\end{array}$ & $\begin{array}{l}\text { Uzundere ilçesinde kadın girişimciliğine yönelik seramik, seracılık ve gastronomi } \\
\text { alanlarında faaliyetler yürütülmektedir. }\end{array}$ \\
\hline GF & $\begin{array}{l}\text { Geleneksel Karakucak } \\
\text { Güreşleri ve Yayla } \\
\text { Festival(ler)i }\end{array}$ & $\begin{array}{l}\text { Uzundere ilçesinde her y1l } 29 \text { Ekimde geleneksel Karakucak Güreşleri, Çamlıyamaç } \\
\text { Köyü’nde Armutlu Festivali, Uluslararası Karakucak Güreşleri (Her y1l mayıs } \\
\text { ayında), Sapaca Köyü Puşulu Yaylası Festivali ve Dikyar Köyü Herfene Şenliği gibi } \\
\text { etkinlikler düzenlenmektedir }\end{array}$ \\
\hline MP & $\begin{array}{l}\text { Mali Destek } \\
\text { Programları } \\
\text { (KUDAKA, DAP BKİ, } \\
\text { TKDK, LEADER, } \\
\text { ERASMUS+, } \\
\text { Bakanlıklar v.b.) }\end{array}$ & $\begin{array}{l}\text { Uzundere ilçesinde faaliyet ve projelere maddi destek sağlayan birçok program } \\
\text { bulunmaktadır. Erzurum Valiliği bünyesinde Sosyal Destek (SODES) proje } \\
\text { finansmanı, Kuzeydoğu Anadolu Kalkınma Ajansının (KUDAKA) çeşitli finansman } \\
\text { destekleri, Tarımsal ve Kırsal Kalkınmayı Destekleme Kurumu'na (TKDK) ait hibe } \\
\text { destekleri, Doğu Anadolu Projesi İdaresi'ne (DAP) ait finansman destekleri, Küçük } \\
\text { ve Orta Büyüklükteki İşletmeleri Geliştirme ve Destekleme İdaresi Başkanlığı'na } \\
\text { (KOSGEB) ait finans destekleri, Avrupa Birliği ve Türkiye Cumhuriyeti tarafindan } \\
\text { finanse edilen IPARD Programı kapsamındaki Kırsal Ekonomik Kalkınma için } \\
\text { Faaliyetler Arasındaki Bağlantılar (LEADER) Yaklaşımı ve bunun haricinde } \\
\text { dönemsel olarak çeşitli bakanlık ve tüzel kişiliklere yönelik finansal programlar } \\
\text { bulunmaktadır. Bu programlardan (şartlara göre değişmekle birlikte) kamu kurum ve } \\
\text { kuruluşları ile vatandaşlar finansal destek (hibe-kredi) alabilmektedirler. }\end{array}$ \\
\hline & $\begin{array}{l}\text { Doğa, Su ve Macera } \\
\text { Sporları ile Yaşam Boyu }\end{array}$ & $\begin{array}{l}\text { Uzundere ilçesinde doğa, su ve macera turizmine yönelik bisiklet, koşu ve } \\
\text { yürüyüş etkinlikleri, kaya tırmanışı, kış mevsiminde buz tırmanışı, trekking, } \\
\text { lkuş gözlemciliği, ilk bahar mevsiminde rafting etkinlikleri, kano ve son }\end{array}$ \\
\hline DF & $\begin{array}{l}\text { Eğitime Yönelik } \\
\text { Uygulamalar }\end{array}$ & $\begin{array}{l}\text { zamanlarda yamaç paraşütü (base jumping), yarasa kanat (wing suit) ve iple } \\
\text { atlama (rope jumping) etkinlikleri düzenlenmektedir. İlçede yaşam boyu } \\
\text { eğitimi desteklemek amacıyla Sakin Şehir Kitap Kafe oluşturularak yerel } \\
\text { halkın kullanımına sunulmuştur. }\end{array}$ \\
\hline KYS & $\begin{array}{l}\text { Kamu, Yerel Yönetim, } \\
\text { Üniversite ve Sivil } \\
\text { Toplum İlişkileri }\end{array}$ & $\begin{array}{l}\text { Uzundere ilçesinde yürütülen proje ve etkinlikler genel olarak Kaymakamlık } \\
\text { ve/veya Belediye koordinasyonunda sağlanmaktadır. İlçede faaliyet yürüten } \\
\text { birçok sivil toplum kuruluşu bulunmakta ve bunun yanında Atatürk } \\
\text { Üniversitesi'nin çeşitli fakültelerinden birçok araştırmacı gerek bağımsız } \\
\text { gerekse de yerel yönetimle işbirliği içinde araştırma ve proje faaliyetleri } \\
\text { yürütmektedir. Ayrıca AB ve Türkiye Cumhuriyeti tarafından finanse } \\
\text { edilen IPARD Programı kapsamında Gıda Tarım ve Hayvancılık Bakanlığ1 } \\
\text { tarafından yürütülen 'LEADER Tedbiri Farkındalı Yaratma ve Yerel Halkı } \\
\text { Harekete Geçirme Teknik Destek Projesi' ile kamu, yerel yönetim, sivil } \\
\text { toplum ve meslek kuruluşu temsilcileri ile yerel eylem grubu } \\
\text { oluşturulmuştur. }\end{array}$ \\
\hline
\end{tabular}

\subsection{Metot}

Çalışmada yöntem olarak etüt, veri toplama, analiz ve değerlendirmeye dayalı peyzaj araştırmaları yöntemi kullanılmıştır (Denzin and Lincoln, 2008). Çalışmanın etüt aşamasında araştırmanın konusu ve amacı belirlenmiştir. Çalışmanın veri toplama aşamasında ilçede yürütülen ve/veya tamamlanan mekânsal tasarım ve uygulamalar ile sosyo-ekonomik, kültürel ve sanatsal faaliyetlerin sürdürülebilirliğinin değerlendirilmesi amaciyla ‘Uzundere Mekânsal Projeler, Faaliyet ve Uygulamalar Anket Formu’ hazırlanmıştır.

Anket formu Ayaşligil (1997), Gündüz (1999), Karvonen (2000), Shu- Yang et al. (2004), WTO (2004), At1l vd. (2005), Aydın (2010), Afacan (2017), Korkut vd. (2017) ve Özcan (2017)'nin çalışmalarından yararlanılarak çalışmanın amaç, veri toplama araçları ve kısıtlılıklarına uygun olarak seçilen kriterler doğrultusunda oluşturulmuştur. Anket soruları çevresel, sosyal ve ekonomik olmak üzere sürdürülebilirliğin üç boyutunu içerecek şekilde; mekânsal tasarım ve uygulama özellikleri, çevresel ve ekolojik özellikler, koruma ve duyarlılıklar ve sosyo-kültürel ve ekonomik özellikler olmak üzere 4 ana kriter altındaki 18 gösterge ile hazırlanmıştır. Çalışmada kullanılan kriter ve göstergeler Tablo 2'de verilmiştir. Anket formu üç bölümden oluşacak şekilde kurgulanmış ve birinci bölümünde katılımcılara ait demografik bilgiler, ikinci bölümünde mekânsal tasarım ve uygulamalar, üçüncü bölümünde ise sosyo-ekonomik, kültürel ve sanatsal faaliyet, proje ve uygulamalar yer almıştır. 
Tablo 2. Çalışmada kullanılan sürdürülebilirlik kriter ve göstergeleri

\begin{tabular}{|c|c|}
\hline $\begin{array}{l}\text { Sürdürülebilirlik } \\
\text { Kriterleri }\end{array}$ & Sürdürülebilirlik Göstergeleri \\
\hline $\begin{array}{l}\text { Mekânsal Tasarım } \\
\text { ve Uygulama } \\
\text { Özellikleri }\end{array}$ & $\begin{array}{l}\text { 1-Yapısal uygulamalar (çizgi, şekil, form) çevrenin doğal görüntüsü ile uyumludur } \\
\text { 2-Kullanılan malzemeler (cins, doku, renk) çevrenin doğal görüntüsü ile uyumludur } \\
\text { 3-Yapılan tasarım/uygulama çevresi ile bütünlük oluşturmaktadır } \\
\text { 1-Uygulama bulunduğu çevrenin doğal/kültürel peyzaj görüntüsünü bozar (çevre estetiğinin } \\
\text { bozulmasi/görüntü/1şık kirliliği) } \\
\text { 2-Uygulama bulunduğu çevrede toprak kirliliğine neden olur } \\
\text { 3-Uygulama bulunduğu çevrede su kirliliğine neden olur }\end{array}$ \\
\hline $\begin{array}{l}\text { Çevresel ve Ekolojik } \\
\text { Özellikler }\end{array}$ & $\begin{array}{l}\text { 4-Uygulama bulunduğu çevrede hava kirliliğine neden olur } \\
\text { 5-Uygulama bulunduğu çevrede gürülttü kirliliğine neden olur } \\
\text { 6-Uygulama bulunduğu çevrede katı atık kirliliğine neden olur } \\
\text { 7-Uygulama çevredeki bitki ve hayvanlara zarar verir } \\
\text { 8-Uygulama bulunduğu alanda insan baskısı oluşturur } \\
\text { 1-Uygulama bulunduğu çevrenin korunmasına katkıda bulunur }\end{array}$ \\
\hline $\begin{array}{l}\text { Koruma ve } \\
\text { Duyarlılıklar }\end{array}$ & $\begin{array}{l}\text { 2-Uygulama bulunduğu ortama bir kimlik kazandırır } \\
\text { 3-Uygulama alanındaki korumaya yönelik kanun, yönetmelik, ilgili mevzuat ve kurul } \\
\text { kararları yeterince uygulanmaktadır. }\end{array}$ \\
\hline Sosyo-Kültürel ve & $\begin{array}{l}\text { 1-Uygulama 1ç̧e nalkına toplumsal tayda saglar (sosyal surdurulebilirlik) } \\
\text { 2-Uygulama yerel kalkınmaya katkıda bulunur (Ekonomik sürdürülebilirlik) }\end{array}$ \\
\hline Ekonomik Özellikler & $\begin{array}{l}\text { 3-Uygulama kültürel sürdürülebilirliğe katk1 sağlar } \\
\text { 4-Uygulama turizmin sürdürülebilirliğine katk1 sağlar }\end{array}$ \\
\hline
\end{tabular}

Anketler Likert ölçeğinden değiştirilerek hazırlanan bir ölçeğe göre oluşturulmuştur (Likert et al., 1934; Bayat, 2014). Katılımcilardan her soru için ortalama puan elde etmek amaciyla sunulan seçeneklere 1 ile 5 arasında değişen puanlar vermeleri istenmiştir. Puanlamada 'çok düşük seçeneği 1, düşük seçeneği 2, orta seçeneği 3, yüksek seçeneği 4 ve çok yüksek seçeneği 5' puanı temsil etmiştir. Anket çalışmasının II. bölümü yerel halk, ziyaretçi ve odak grup ile yapılırken; III. bölümü ziyaretçi grubunun ilçede yürütülen sosyo-ekonomik, kültürel ve sanatsal faaliyetler hakkında bilgi sahibi olamayabilecekleri düşünülerek ile sadece yerel halk ve odak grup ile yapılmıştır.

Çalışma ile değerlendirmeye tabi tutulacak olan tasarım çalışmalarının görselleri ilgili firma ve internet ortamından, uygulamaların görselleri ise fotoğrafları çekilerek elde edilmiştir. Çalışmaya başlamadan önce katılımcılara sürdürülebilirlik kavramıyla ilgili açıklayıcı bilgiler verilmiş ve her bir tasarım ve uygulamanın görselleri gösterilerek bu doğrultuda bir puanlama yapmaları istenmiştir.

Katılımcı gruplarındaki örneklem büyüklükleri (kişi sayısı-n) Özdamar (2003) ve Yazıcığlu ve Erdoğan (2004)'ün çalışmalarından yararlanılarak, $\mathrm{n}=\frac{\mathrm{N} \cdot \mathrm{t}^{2} \cdot \mathrm{p} \cdot \mathrm{q}}{(\mathrm{N}-1) \cdot \mathrm{d}^{2}+\mathrm{t}^{2} \cdot \mathrm{p} \cdot \mathrm{q}}$ formülüne göre $\mathrm{d}=0,10$ örnekleme hatası (95\% güven aralığı) ve $\mathrm{p}=0,5$ gözlenme oranı esas alınarak hesaplanmıştır.

- $n$ : Örneklem büyüklüğü

- $\quad \mathrm{N}$ : Evrendeki birim sayıs1

- $\mathrm{t}$ : $\mathrm{t}$ tablosundan bulunan değer (95\% güven aralığında $\alpha=0.05$ için t değeri 1.96 bulunmuştur)

- $\mathrm{d}$ : Örneklem hatası

- p: İncelenen olayın görülme oranı

- q: İncelenen olayın görülmeme oranı

Buna göre yerel halk grubu (YHG) Uzundere ilçe nüfusu dikkate alınarak (2018 y1lı ilçe nüfusu 8800 olarak alınmıştır) 94 kişi (n) olarak hesaplanmış fakat 100 kişi ile anket çalışması yürütülmüştür. Ziyaretçi grubunun (ZG) hesaplanmasında ilçenin yıllık ziyaretçi sayılarına ulaşılmaya çalışılmış ancak TÜIK, Kültür ve Turizm İl Müdürlüğü ve Erzurum İl Emniyet Müdürlüğü ile yapılan yazışmalar sonucunda ilçenin yıllık ziyaretçi sayısına ait herhangi bir veri olmadığından dolayı yerel halk grubu ile aynı örneklem büyüklüğü olması açısından 100 kişiden oluşturulmuştur. Ziyaretçi grubu katılımcıları, günübirlik yada konaklamalı ziyaret amacıyla ilçede bulunan kişiler arasından rastlantısal olarak seçilmiştir. Odak grup (OG) ise ilçede yürütülen mekânsal tasarım, uygulamalar ve diğer kalkınma girişimleriyle ilgili bilgi sahibi olan yerel yönetim, ekonomi, turizm, ziraat ve peyzaj planlama ve tasarımı gibi alanlarda faaliyetler yürüten 49 kişiden (n) oluşturulmuştur. Ancak bu 49 kişilik grubun 40'ı anket çalışmalarına katılmıştır.

Çalışmanın analiz bölümünde anket çalışması ile elde edilen veriler analiz edilmiştir. Anketlerin analizi IBM SPSS Statistics 24 programı ile yapılmıştır ve kriterlere ait göstergelerin aritmetik ortalaması ile kriter ortalama puanları oluşturulmuştur. Çalışma kapsamında One-Way ANOVA (Analysis of Variance) ve bağımsız örneklem 
T testi (Independent-Samples T Test) olmak üzere iki farklı istatistiki analiz kullanılmıştır. Anket çalışmasının II. bölümü üç farklı katılımcı grubu ile yürütüldüğünden gruplara göre kriterlerin almış olduğu ortalama puanlar arasında istatistiki olarak anlamlı bir fark olup olmadığını belirlemek amacıyla One-Way ANOVA (Analysis of Variance) testi yapılmıştır. Oluşan anlamlı farkların hangi iki grup arasında gerçekleştiğini belirlemek için Post Hoc test türlerinden Games-Howell ve Tukey testi yapılmıştır. Analizlerde önem değeri (sig.= p) olarak 0.05 (95\% güven aralığında $\mathrm{p}=0.05)$ kullanılmıştır. Anket çalışmasının III. bölümü ise iki farklı katılımcı grubu ile yürütüldüğü için bağımsız örneklem T testi (Independent-Samples T Test) yapılmıştır.

Çalışmanın değerlendirme bölümünde ise ilçede yürütülen mekânsal tasarım ve uygulama çalışmaları ile sosyal, ekonomik, kültürel ve sanatsal faaliyetlerin analiz edilmiş verilerine göre kalitatif bir sürdürülebilirlik değerlendirmesi gerçekleştirilmiştir.

\section{Bulgular ve Tartışma}

Anket çalışmalarına katılan grupların demografik özelliklerine ait bilgiler Tablo 3 ’te verilmiştir.

Tablo 3. Katılımcı grupların demografik özellikleri

\begin{tabular}{|c|c|c|c|c|c|c|c|}
\hline \multirow[t]{2}{*}{ Kriterler } & \multirow[t]{2}{*}{ Alt Kriterler } & \multicolumn{2}{|c|}{$\begin{array}{c}\text { Yerel Halk } \\
\text { Grubu }\end{array}$} & \multicolumn{2}{|c|}{$\begin{array}{c}\text { Ziyaretçi } \\
\text { Grubu }\end{array}$} & \multicolumn{2}{|c|}{$\begin{array}{l}\text { Odak } \\
\text { Grup }\end{array}$} \\
\hline & & $\mathbf{n}$ & $\%$ & $\mathbf{n}$ & $\%$ & $\mathbf{n}$ & $\%$ \\
\hline \multirow{4}{*}{ Cinsiyet } & Erkek & 62 & 62,0 & 55 & 55,0 & 27 & 67,5 \\
\hline & Kadın & 38 & 38,0 & 45 & 45,0 & 13 & 32.5 \\
\hline & Toplam & 100 & 100 & 100 & 100 & 40 & 100 \\
\hline & $16-25$ & 18 & 18,0 & 29 & 29,0 & 0 & 0 \\
\hline \multirow{5}{*}{ Yaş } & $26-35$ & 42 & 42,0 & 43 & 43,0 & 11 & 27,5 \\
\hline & $36-45$ & 28 & 28,0 & 23 & 23,0 & 23 & 57,5 \\
\hline & $46-55$ & 10 & 10,0 & 4 & 4,0 & 3 & 7,5 \\
\hline & 56 ve üstü & 2 & 2,0 & 1 & 1,0 & 3 & 7,5 \\
\hline & Toplam & 100 & 100 & 100 & 100 & 40 & 100 \\
\hline \multirow{6}{*}{$\begin{array}{c}\text { Eğitim } \\
\text { Durumu }\end{array}$} & İlköğretim & 9 & 9,0 & 3 & 3,0 & 0 & 0 \\
\hline & Lise & 35 & 35,0 & 22 & 22,0 & 2 & 5,0 \\
\hline & Ön Lisans-Lisans & 50 & 50,0 & 53 & 53,0 & 12 & 30,0 \\
\hline & Lisans Üstü & 6 & 6,0 & 22 & 22,0 & 26 & 65,0 \\
\hline & Toplam & 100 & 100 & 100 & 100 & 40 & 100 \\
\hline & Eğitim sektörü çalışanı & 22 & 22,0 & 31 & 31,0 & 18 & 45,0 \\
\hline \multirow{9}{*}{$\begin{array}{c}\text { Faaliyet } \\
\text { Alanı }\end{array}$} & Tarım sektörü çalışanı & 5 & 5,0 & 5 & 5,0 & 2 & 5,0 \\
\hline & Sağlık sektörü çalışanı & 9 & 9,0 & 10 & 10,0 & 0 & 0 \\
\hline & Ulaşım sektörü çalışanı & 5 & 5,0 & 5 & 5,0 & 1 & 2,5 \\
\hline & İnşaat sektörü çalışanı & 3 & 3,0 & 8 & 8,0 & 1 & 2,5 \\
\hline & Turizm sektörü çalıșanı & 3 & 3,0 & 2 & 2,0 & 4 & 10,0 \\
\hline & Öğrenci & 6 & 6,0 & 16 & 16,0 & 1 & 2,5 \\
\hline & İşsiz & 2 & 2,0 & 1 & 1,0 & 0 & 0 \\
\hline & Diğer & 45 & 45,0 & 22 & 22,0 & 13 & 32,5 \\
\hline & Toplam & 100 & 100 & 100 & 100 & 40 & 100 \\
\hline \multirow{5}{*}{$\begin{array}{c}\text { Gelir } \\
\text { Durumu }\end{array}$} & 2000 TL alt 1 & 20 & 20,0 & 24 & 24,0 & 0 & 0 \\
\hline & 2001-5000 TL arası & 67 & 67,0 & 44 & 44,0 & 12 & 30,0 \\
\hline & $5001-10.000 \mathrm{TL}$ aras 1 & 13 & 13,0 & 32 & 32,0 & 19 & 47,5 \\
\hline & 10.0001TL üstü & 0 & 0 & 0 & 0 & 9 & 22,5 \\
\hline & Toplam & 100 & 100 & 100 & 100 & 40 & 100 \\
\hline
\end{tabular}

Tablo 3' e göre her üç gruptaki katılımcıların büyü çoğunluğu erkeklerden oluşmaktadır. Yerel halk ve ziyaretçi grubu katılımcılarının büyük çoğunluğu 26-35 yaş grubundayken, odak grubun büyük çoğunluğu 36-45 yaş grubundadır. Eğitim durumu bakımından odak grup 65\% ile lisansüstü seviyesinde eğitime sahipken, yerel halk grubu 50\%, ziyaretçi grubu ise 53\% ile lisans seviyesindeki eğitime sahiptir.

Anket çalışması sonucunda mekânsal tasarım ve uygulama çalışmaları ile diğer faaliyetlerin mekânsal tasarım ve uygulama özellikleri, çevresel ve ekolojik özellikler, koruma ve duyarlılıklar ve sosyo- kültürel ve ekonomik özellikler yönünden katılımcı gruplara göre aldıkları ortalama puanlar ve istatistiki olarak anlamlı farklılaşmalar Tablo 4'te verilmiştir. 
Tablo 4. Anket analiz sonuçları

\begin{tabular}{|c|c|c|c|c|c|c|c|c|c|c|c|c|}
\hline & \multicolumn{3}{|c|}{$\begin{array}{l}\text { Mekânsal Tasarım ve } \\
\text { Uygulama Özellikleri }\end{array}$} & \multicolumn{3}{|c|}{$\begin{array}{c}\text { Çevresel ve Ekolojik } \\
\text { Özellikler }\end{array}$} & \multicolumn{3}{|c|}{$\begin{array}{c}\text { Koruma ve } \\
\text { Duyarlılıklar } \\
\end{array}$} & \multicolumn{3}{|c|}{$\begin{array}{c}\text { Sosyo- Kültürel ve } \\
\text { Ekonomik Özellikler }\end{array}$} \\
\hline & YHG & ZG & OG & YHG & $\mathbf{Z G}$ & OG & YHG & $\mathbf{Z G}$ & OG & YHG & $\mathbf{Z G}$ & OG \\
\hline YG & $\begin{array}{l}3,600^{*} \\
\mathrm{p}=, 000\end{array}$ & 3,420 & $2,641^{*}$ & $\begin{array}{l}2,081 \\
p=, 110\end{array}$ & 2,351 & 2,237 & $\begin{array}{l}3,246^{* *} \\
\mathrm{p}=, 000\end{array}$ & $2,920^{*}$ & $2,475^{*}$ & $\begin{array}{l}3,932 * \\
\mathrm{p}=, 002\end{array}$ & $3,737^{*}$ & $3,200^{* *}$ \\
\hline TŞ & $\begin{array}{l}3,750^{*} \\
\mathrm{p}=, 000\end{array}$ & $3,693^{*}$ & 1,941 ** & $\begin{array}{l}2,135 \\
p=, 234\end{array}$ & 2,333 & 2,334 & $\begin{array}{l}3,326^{*} \\
p=, 000\end{array}$ & $3,330 *$ & $2,491 * *$ & $\begin{array}{l}4,145^{*} \\
\mathrm{p}=, 000\end{array}$ & $4,262 *$ & $3,087^{* *}$ \\
\hline UY & $\begin{array}{l}3,763^{*} \\
\mathrm{p}=, 000\end{array}$ & $3,9367^{*}$ & $2,483^{* * *}$ & $\begin{array}{l}2,127 \\
\mathrm{p}=, 195\end{array}$ & 2,238 & 2,400 & $\begin{array}{l}3,216^{*} \\
\mathrm{p}=, 000\end{array}$ & $3,486^{*}$ & $2,300^{* *}$ & $\begin{array}{l}4,102 * \\
\mathrm{p}=, 000\end{array}$ & $4,205^{*}$ & $2,881 * *$ \\
\hline CT & $\begin{array}{l}3,486^{*} \\
\mathrm{p}=, 000\end{array}$ & $3,336^{*}$ & $2,641 * *$ & $\begin{array}{l}2,053 \\
\mathrm{p}=, 854\end{array}$ & 2,077 & 2,137 & $\begin{array}{l}3,296^{*} \\
\mathrm{p}=, 001\end{array}$ & $3,163^{*}$ & $2,683^{* *}$ & $\begin{array}{l}3,912 * \\
\mathrm{p}=, 010\end{array}$ & $4,025^{*}$ & $3,431 * *$ \\
\hline TÇ & $\begin{array}{l}3,766^{*} \\
\mathrm{p}=, 000\end{array}$ & $3,810^{*}$ & $3,108^{* *}$ & $\begin{array}{l}2,105 \\
\mathrm{p}=, 690\end{array}$ & 2,112 & 2,243 & $\begin{array}{l}3,236 \\
\mathrm{p}=, 064\end{array}$ & 3,146 & 2,833 & $\begin{array}{l}3,987 \\
\mathrm{p}=, 092\end{array}$ & 3,875 & 3,581 \\
\hline DY & $\begin{array}{l}3,726^{*} \\
\mathrm{p}=, 000\end{array}$ & $3,766^{*}$ & $2,966^{* * *}$ & $\begin{array}{l}2,127 \\
\mathrm{p}=, 159\end{array}$ & 2,201 & 2,450 & $\begin{array}{l}3,156^{*} \\
\mathrm{p}=, 009\end{array}$ & $3,036^{*}$ & $2,625^{* * *}$ & $\begin{array}{l}4,045^{*} \\
\mathrm{p}=, 006\end{array}$ & $3,922 *$ & $3,456^{* *}$ \\
\hline BO & $\begin{array}{l}3,8900^{*} \\
p=, 000\end{array}$ & $3,810^{*}$ & $3,108^{* * *}$ & $\begin{array}{l}1,993 \\
p=, 762\end{array}$ & 1,955 & 1,887 & $\begin{array}{l}3,196 \\
p=, 241\end{array}$ & 3,146 & 2,950 & $\begin{array}{l}3,937 \\
p=, 830\end{array}$ & 3,957 & 3,856 \\
\hline
\end{tabular}

Tablo 4. Tablo devam ediyor

\begin{tabular}{|c|c|c|c|c|c|c|c|c|c|c|c|c|}
\hline TÇI & $3,270 *$ & $\begin{array}{c}2,766^{* *} \\
p=, 000\end{array}$ & $2,166^{* * * *}$ & 3,116 & $\begin{array}{l}2,860 \\
p=, 218\end{array}$ & 2,191 & $3,497 *$ & $\begin{array}{l}3,145^{*} \\
\mathrm{p}=, 000\end{array}$ & $2,606^{* * *}$ & $3,497 *$ & $\begin{array}{c}3,145 \\
\mathrm{p}=, 001\end{array}$ & $2,606^{*}$ \\
\hline SU & 3,860 & $\begin{array}{c}4,023^{*} \\
\mathrm{p}=, 009\end{array}$ & $3,558^{*}$ & $2,028^{*}$ & $\begin{array}{l}2,010^{*} \\
\mathrm{p}=, 000\end{array}$ & $1,490 * *$ & 3,260 & $\begin{array}{l}3,083 \\
\mathrm{p}=, 309\end{array}$ & 3,075 & $4,352^{*}$ & $\begin{array}{c}4,265 \\
\mathrm{p}=, 022\end{array}$ & $3,881^{*}$ \\
\hline & YHG & OG & p & YHG & OG & p & YHG & OG & p & YHG & OG & p \\
\hline KBC & 3,400 & 2,516 &, $000^{*}$ & 1,927 & 2,100 & ,290 & 3,110 & 3,650 &, $000 *$ & 3,690 & 3,025 & ,006* \\
\hline KİC & 3,493 & 3,658 & ,365 & 2,140 & 1,800 &, $024 *$ & 3,110 & 3,650 &, $000 *$ & 3,590 & 4,037 &, $012 *$ \\
\hline SM & 3,040 & 2,433 &, $012 *$ & 1,750 & 2,100 &, $020^{*}$ & 2,850 & 2,491 & ,151 & 3,337 & 2,925 & 134 \\
\hline EK & 3,016 & 2,375 &, $004 *$ & 1,750 & 2,100 &, $020 *$ & 2,883 & 2,408 &, $048 *$ & 3,197 & 2,893 & ,236 \\
\hline KDB & - & - & - & 1,786 & 1,206 &, $000^{*}$ & 3,133 & 3,833 &, $000 *$ & 3,807 & 4,606 &, $000 *$ \\
\hline EP & - & - & - & 1,893 & 1,550 &, $004 *$ & 2,883 & 2,408 &, $048 *$ & 3,647 & 4,287 &, $000 *$ \\
\hline KG & - & - & - & 1,892 & 1,253 &, $000 *$ & 3,106 & 3,558 & ,003* & 3,867 & 4,481 &, $000 *$ \\
\hline GF & - & - & - & 1,913 & 1,868 & ,733 & 3,133 & 3,191 & ,706 & 3,792 & 4,387 &, $000 *$ \\
\hline DF & - & - & - & 1,806 & 1,628 & ,106 & 3,206 & 3,300 & ,515 & 3,732 & 4,262 &, $000 *$ \\
\hline KYS & - & - & - & - & - & - & 3,566 & 3,466 & 492 & 3,900 & 4,262 &, $015^{*}$ \\
\hline MP & - & - & - & - & - & - & 3,6000 & 3,508 & 610 & 4,045 & 4,381 &, $025^{*}$ \\
\hline
\end{tabular}

Tablo 4'e göre anket çalışmasının II. bölümünde yer alan mekânsal tasarım ve uygulamalar içerisinde mekânsal tasarım ve uygulama özellikleri bakımından Yedigöller çevre düzenleme çalışmaları, Tortum Şelalesi ve çevresi peyzaj tasarımı ve uygulamaları, Uzunburun Yarımadası peyzaj tasarımı, Tortum Gölü cam teras (fiyort park) tasarımı ve uygulaması ve Uzundere-Tortum Çayı ıslah çalışmasına odak grup tarafindan düşük puan verildiği ve sürdürülebilir olarak değerlendirilmediği görülmektedir. Bununla beraber mekânsal tasarım ve uygulama özelliklerine ait sorulara verilen cevaplar genel olarak yerel halk grubu ve ziyaretçi grubu arasında istatistiki olarak anlamlı bir şekilde farklılaşmazken, odak grubun vermiş olduğu cevaplar yerel halk ve ziyaretçi grubuna göre anlamlı bir şekilde farklılaşmıştır. Anket çalışmasının III. bölümünde yer alan kamu binaları ve çevre düzenleme uygulamaları, sivil mimari ve ikinci konut uygulamaları ve Engüzekkapı Kalesi çevre düzenleme uygulamaları da mekânsal tasarım ve uygulama özellikleri yönünden ise odak grup tarafindan düşük bir ortalama puan verilerek sürdürülebilir olarak değerlendirilmemiştir. Sorulara gruplar tarafindan verilen cevaplar kent imajı geliştirme çalışmaları haricinde istatistiki olarak anlamlı bir şekilde farklılaşmıştır. Mekânsal tasarım ve uygulama özellikleri yönünden sürdürülebilir olarak değerlendirilmeyen çalışmalar Şekil 3 ’te verilmiştir. 


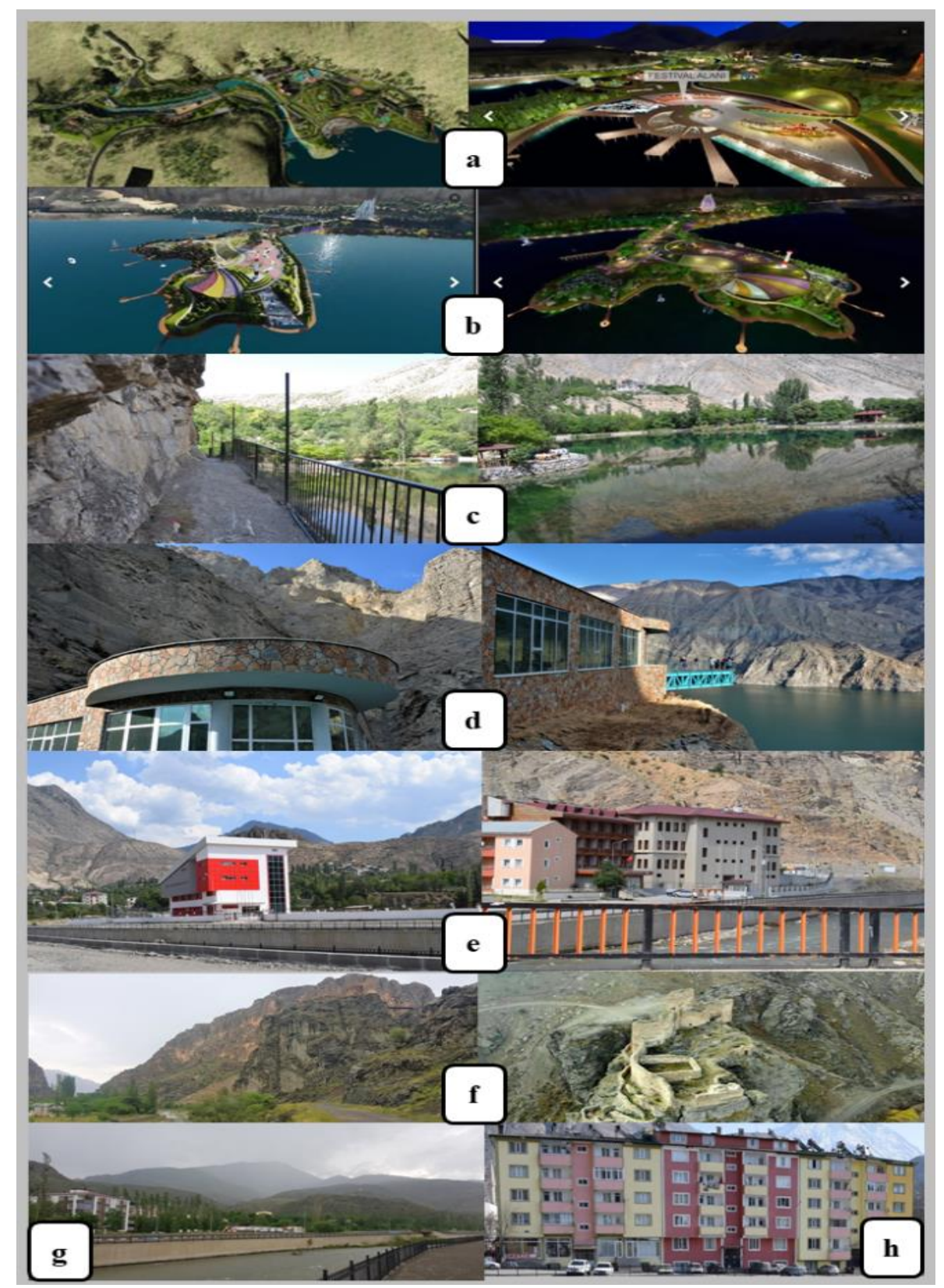

Şekil 3. Mekânsal tasarım ve uygulama özellikleri yönünden sürdürülebilir olarak değerlendirilmeyen çalışmalar (a-Tortum Şelalesi peyzaj tasarım ve uygulaması b-Uzunburun Yarımadası peyzaj tasarımı c-Yedigöller çevre düzenleme çalışmaları d-Tortum Gölü fiyort park tasarımı ve uygulaması e-kamu binaları ve çevre düzenleme uygulamaları fEngüzekkapı Kalesi çevre düzenleme çalışmaları g-Tortum Çayı ıslah çalışması h-Sivil mimari ve ikinci konut uygulamaları)

Çevresel ve ekolojik özelliklere ait sorular anlam bakımından olumsuz olduğu için ortalama puanların düşük olması daha olumlu bir sonuç anlamına gelmektedir. Dolayısıyla her üç grup bakımından da çalışmalara ait ortalama puanların üçün (3) altında kalması, katılımcı grupların çalışmaları çevresel ve ekolojik özellikler bakımından düşük seviyede riskli gördüğ̈̈ şeklinde değerlendirilmiştir. Çevresel ve ekolojik özelliklere ait sorulara katılımcı grupların vermiş olduğu cevapların farklılaşmasına bakıldığında ise Sakin Şehir tanıtım uygulamaları, ev pansiyonculuğu uygulamaları, kadın girişimciliği uygulamaları, Gölbaşı kapama dut bahçesi uygulaması, Engüzekkapı Kalesi çevre düzenleme çalışmaları, sivil mimari ve ikinci konut uygulamaları ve kent imajı geliştirme ve sokak sağlıklaştırma uygulamalarında anlamlı bir şekilde farklılaşırken, diğer tasarım ve uygulamalarda anlamlı bir farklılaşma olmamıştır.

Koruma ve duyarlılıklar bakımından anket çalışmasının ikinci bölümünde yer alan tasarım ve uygulamalar içerisinde sadece Sakin Şehir (Uzundere) tanıtım uygulamaları odak grup tarafından sürdürülebilir olarak değerlendirilmiştir (Şekil 4). Anket çalışmasının üçüncü bölümünde yer alan tasarım uygulama ve faaliyetlerden ise sivil mimari ve ikinci konut uygulamaları, ev pansiyonculuğu uygulamaları ve Engüzekkapı Kalesi çevre 
düzenleme çalışmaları ve sivil mimari ve ikinci konut uygulamaları odak grup tarafından sürdürülebilir olarak değerlendirilmemiştir. Bunun yanında grupların sorulara verdiği cevaplar genel olarak odak grup ile yerel halk ve/veya ziyaretçi grup şeklinde anlamlı bir şekilde farklılaşmıştır.

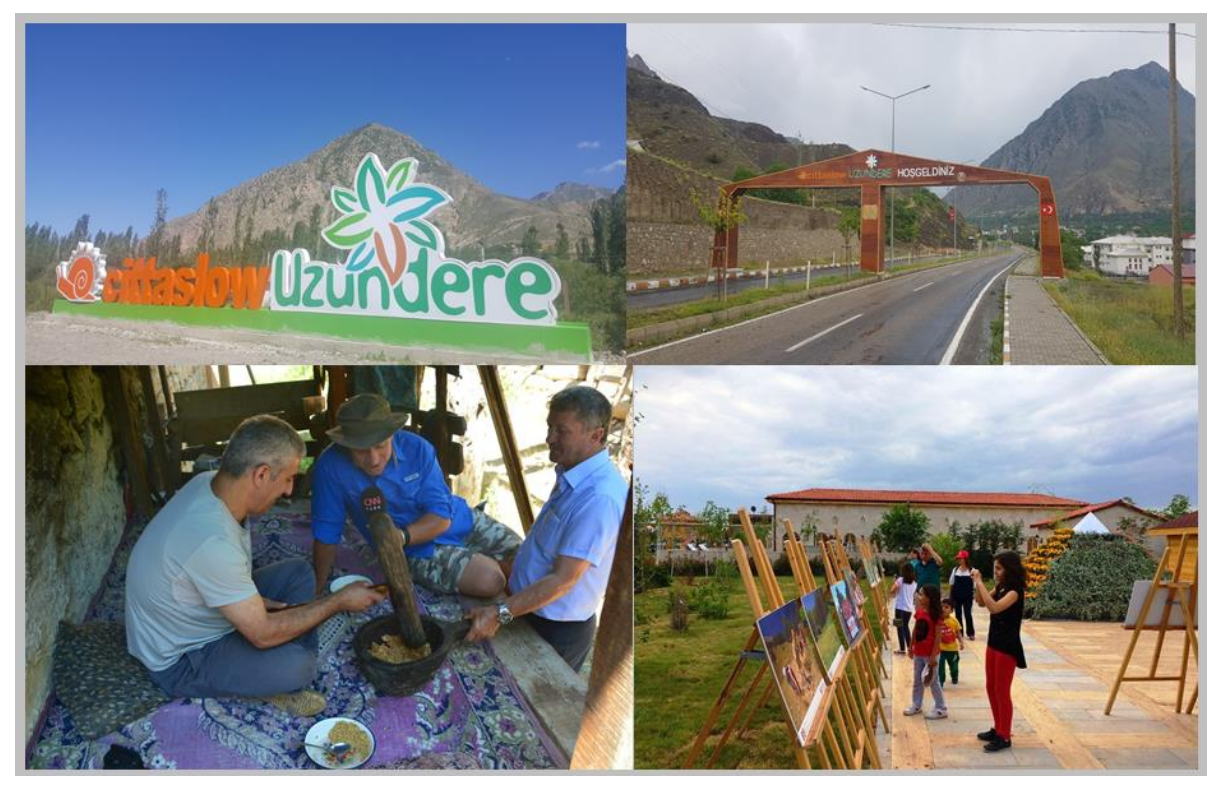

Şekil 4. Sakin Şehir Uzundere tanıtım uygulamalarından bazı örnekler

Turizm destinasyonlarındaki kalkınma odaklı girişimler için kapsamlı bir çalışma sunan Dünya Turizm Örgütü (WTO), çevresel (tasarımsal, ekolojik çevresel özellikler, doğal kaynaklar ve koruma işlevi), sosyo-kültürel ve ekonomik boyutlara dikkat çekerek, yerel halk ve yerel çevre için faydalar sağlamayı hedeflemektedir. Turizm destinasyonlarında çekiciliği oluşturan ana unsurlardan biri bozulmamış bir doğadır (Page and Connell, 2006). WTO (2004), bir mekânsal tasarımın fiziksel ve kültürel bağlamında tasarlanması gerektiğini bildirerek, yapısal uygulamaların renk, doku ve formunun çevre ile bütünlük oluşturmasına ve geleneksel mimari ile uyumlu olmasına dikkat çekmektedir. Doğal ve kültürel çevre ile uyumlu olmayan, plansız ve/veya kötü tasarlanmış tasarım ve uygulama girişimleri, ziyaretçileri çeken ve turizm arzını oluşturan doğal ve beşeri çevreye olumsuz tepkiler vererek yıpratabilmekte ve görsel kirlilik oluşturabilmektedir (Inskeep, 1991). Özellikle kırsal doku ve kültürün hakim olduğu alanlar, bu yıpranmaya karşı daha hassastır. Doğal ve kültürel peyzajı bozan, turizm arzını oluşturan kaynakları olumsuz etkileyen mekânsal tasarım çalışmaları ve fiziki uygulamalar kısa vadede ekonomik getiriler sağlasa bile zamanla alanın doğal ve kültürel peyzaj kaynak değerlerinden oluşan tüm turizm cazibesini yitirmesine neden olabilmektedir.

Bunun yanında yerel halk için sosyal, kültürel ve ekonomik faydalar sağlamayan faaliyetler de sürdürülebilirlik tartışması ile karşı karşıya kalabilmektedir. Harris (2000) sosyo-kültürel, ekonomik ve çevresel boyutların sentezinin sürdürülebilir kalkınmanın başarısı için temel şart olduğunu belirtmektedir (Özmete, 2011). Tüm bunlardan hareketle kırsal dokunun hakim olduğu alanlarda yürütülen tasarım ve uygulama girişimleri için estetik değerlendirme süreçlerinin işletilmesinin sürdürülebilir kalkınma için önemli bir gereksinim olduğu söylenebilir.

Anket çalışmasının sonuçları, yerel halk grubu, ziyaretçi grubu ve odak grubun çalışmalara genel olarak farklı bir bakış ile yaklaştıklarını göstermektedir. Odak grup değerlendirilen çalışmalara mekânsal tasarım ve uygulama özellikleri, koruma ve duyarlılıklar ve sosyo- kültürel ve ekonomik özellikler bakımından genel olarak daha düşük ortalama puanlar verirken, yerel halk grubu ve ziyaretçi grubu daha yüksek puanlar vermiş ve büyük oranda istatistiki olarak anlamlı farklılaşmalar olmuştur. Anket sorularına verilen cevaplar katılımcıların demografik özelliklerine (cinsiyet, yaş, meslek, gelir, eğitim v.b.) göre farklılık gösterebilir (Elinç, 2011, Özgeriş ve Karahan, 2015). Bu farklılığa katılımcıların algıları ve değerlendirmeleri neden olabileceği gibi katılımcı grubun kendisi de neden olabilir. Çünkü katılımcı gruba göre beklentiler ve hassasiyetler de farklılaşabilmektedir. Örneğin, çalışmada yerel halk grubunun sosyo-kültürel ve ekonomik özellikler bakımından genel olarak en yüksek puanları vermesinin bir nedeni, yerel halk grubunun sosyo-ekonomik beklentileri olabilir. Yerel halk grubunun turizmden sosyo-ekonomik beklentileri çevresel ve ekolojik etkileri göz ardı etmesine de yol açabilir (Çalışkan ve Tütüncü, 2008). Ziyaretçi grubunun ise rekreasyon ve görsellik gibi beklentileri verilen cevapları etkileyebilirken odak grup hem demografik özellikleri hem de çevresel hassasiyetleri sebebiyle, ekolojik olarak daha duyarlı bir yaklaşım sergilemiş olabilir. Bu nedenle kullanıcı bakış için ziyaretçiler, faydalanıcı bakış için yerel halk, koruma ve duyarlılık bakışı için ise odak yada uzman grup planlama ve tasarım faaliyetlerine üç eksen olarak dahil 
edilmelidir. Bu üç ekseni planlama ve tasarım faaliyetlerine dahil etmeyen her çalışma koruma-kullanıma ek olarak faydalanma dengesini de sağlamaktan, dolayısıyla sürdürülebilir olmaktan uzak olacaktır. Nitekim WTO ve Küresel Sürdürülebilir Turizm Konseyi (GSTC) gibi kuruluşlar da sürdürülebilir kalkınma için geniş paydaş katılımlı planlama ve tasarım süreçlerini ön plana çıkarmaktadır. Geniş paydaş katılımlı planlama ve tasarım süreçleri aynı zamanda sürdürülebilirlik anlayışının kesintiye uğramadan devam etmesinin sağlayacak, kurumsal sürdürülebilirlik kültürünün oluşmasına da katkıda bulunabilir.

\section{Sonuç ve Öneriler}

Bu çalışma Erzurum ili Sakin Şehir (Cittaslow) Uzundere ilçesindeki özellikle son 15 yılda yerel kalkınmanın bir aracı olarak ve büyük çoğunluğu turizmle ilişkili olan mekânsal tasarım ve uygulama çalışmaları ile sosyoekonomik, kültürel ve sanatsal faaliyetler üzerinde yürütülmüştür. Çalışmanın amacı Uzundere ilçesinde kalkınma odaklı yürütülen mekânsal tasarım ve uygulama girişimleri ile diğer faaliyetlerin sürdürülebilirliğinin ve/veya sürdürülebilirliğe katkısının değerlendirilmesidir. Bu amaca yönelik olarak çalışma kapsamında mekânsal proje, faaliyet ve uygulamalar anketi hazırlanarak, yerel halk grubu, ziyaretçi grup ve odak grup olmak üzere üç farklı grup ile anket çalışması yapılmıştır.

Çalışmanın sonuçlarına göre ilçede yürütülen mekânsal tasarım ve uygulama çalışmaları ile sosyal, ekonomik, kültürel ve sanatsal faaliyetlerin büyük çoğunluğu, odak grup tarafından mekânsal tasarım ve uygulama özellikleri bakımından sürdürülebilir olarak değerlendirilmemiştir. Bunun yanında tüm çalışmalar çevresel ve ekolojik özellikler bakımından sürdürülebilir olarak değerlendirilirken, sosyo-kültürel ve ekonomik özellikler bakımından büyük çoğunluğu, koruma ve duyarlılıklar bakımından ise çoğunluğu orta, yüksek yada çok yükseğe yakın seviyede sürdürülebilir olarak değerlendirilmiştir.

Çalışma ile yerel halk grubu, ziyaretçi grubu ve odak grubun vermiş olduğu cevaplar arasında istatistiki olarak anlamlı farklılaşmalar tespit edilmiştir. Bu anlamlı farklılaşmalara;

- Katılımcıların demografik özellikleri

- Katılımcıların alg1 ve değerlendirmeleri ve

- Grupların (yerel halk, ziyaretçi ve odak grup) beklenti ve hassasiyetlerinin neden olabileceği değerlendirilmiştir.

Sonuç olarak kalkınma odaklı mekânsal tasarım ve uygulama girişimlerinin sürdürülebilirliğinin sağlanması için

- Yapılan çalışmaların koruma (uzmanlar), kullanım (ziyaretçiler) ve faydalanma (yerel halk) temelinde, tüm paydaşları sürece dahil ederek, kurumsallaşmış bir sürdürülebilirlik anlayışı ile yürütülmesi

- Yapılan çalışmaların özellikle kırsal dokunun hakim olduğu alanlarda doğal ve kültürel peyzaj ile uyumlu olması ve bunu sağlamak için çalışmalarda estetik değerlendirme süreçlerinin işletilmesi

- Çalışmaların sürdürülebilir kalkınmanın ihtiyaç duyduğu sosyo-kültürel, ekonomik ve çevresel boyutlarıyla ele alınarak planlanması ve tasarlanması önerilmektedir.

\section{Kaynaklar}

1. Acuner, E. (2015). Zigana Turizm Merkezi'nin Sürdürülebilir Turizm Kriterleri Çerçevesinde Yerel Destinasyon Yönetim Örgütleri Tarafından Değerlendirilmesi. Gazi Üniversitesi Turizm Fakültesi Dergisi 1 (2015), 62-93.

2. Afacan, G. (2017). Seferihisar'daki Turizm Yapılarının Sürdürülebilir Tasarım İlkeleri Doğrultusunda İncelenmesi. Y. Lisans Tezi, Dokuz Eylül Üniversitesi Fen Bilimleri Enstitüsü, İzmir.

3. Aksu, C. (2011). Sürdürülebilir Kalkınma ve Çevre. Güney Ege Kalkınma Ajansı http://cevre.mf.duzce.edu.tr/Dokumanlar/cevre_mf/Dosyalar/S\%C3\%9CRD\%C3\%9CR\%C3\%9CLEB\%C 4\%B0L\%C4\%B0R\%20Kalk\%C4\%B1nma\%20ve\%20\%C3\%87evre.pdf (20.10.2018)

4. Alkin, E. (2008). İktisada Giriş, (11-20 Ünite), Editör: İlyas Şıklar, T.C. Anadolu Üniversitesi Yayınları, 7. Baskı, Eskişehir, Kasım

5. Atalay, İ. (1979). Geomorphology of the Lake Tortum and Its Immediate Surroundings (NE Turkey). Review of the Geographical Institute of the University of Istanbul, İnternational Edition, Number: 17, 4965.

6. Atıl, A., Gülgün, B., Yörük, İ. (2005). Sürdürülebilir Kentler ve Peyzaj Mimarlığı. Ege Üniversitesi Ziraat Fakültesi Dergisi, 42, 215-226. 
7. Ayaşlıgil, Y. (1997). Ekolojik Planlama Dersi Basılmamış Ders Notları. İÜ Orman Fakültesi Peyzaj Mimarlığı Bölümü Yüksek Lisans Programı. İstanbul.

8. Aydın, B. (2010). Gelişme Alanlarında Ekolojik Kentsel Yerleşim Kriterlerinin Belirlenmesi ve İmar Planı Kapsamında Yorumlanması: Ömerli Havzası-Sancaktepe Örneği. Y. Lisans Tezi, İstanbul Teknik Üniversitesi Fen Bilimleri Enstitüsü, İstanbul.

9. Bahtiyar Karadeniz, C. (2014). Sürdürülebilir Turizm Bağlamında Sakin Şehir Perşembe. Uluslararası Sosyal Araştırmalar Dergisi, 7 (29), 84-107.

10. Bayat, B. (2014). Uygulamalı Sosyal Bilim Araştırmalarında Ölçme, Ölçekler ve Likert Ölçek Kurma Tekniği. Gazi Üniversitesi İktisadi ve İdari Bilimler Fakültesi Dergisi, 16 (3), 1-24.

11. Beyhan, E. (2008). Sürdürülebilir Kalkınma - Çevre ve Yerel Yönetimler. Yerel Siyaset Ayllk Bilimsel Siyasi Dergi, 35, 12-17.

12. CEPF (2003). Critical Ecosystem Partnership Fund. Ecosystem Profle, Caucasus Bioiversity Hotspot. https ://www.cepf.net/our-work/biodiversityhotspots/caucasus. (30.11.2019)

13. Çalışkan, Ö., Tütüncü, Ö. (2008). Turizmin Yerel Halk Üzerindeki Etkileri ve Kuşadası İlçesi Uygulaması. IV. Lisansüstü Turizm Öğrencileri Araştırma Kongresi Bildiriler Kitabı, 127-148.

14. Denzin, N.K., Lincoln, Y.S. (2008). The Landscape of Qualit ative Research. Sage Publications, London, 615 pages.

15. EDTMP (2013). Erzurum Doğa Turizmi Master Planı 2013-2023. Orman ve Su İşleri Bakanlığı Doğa Koruma ve Milli Parklar Genel Müdürlüğü, Erzurum, 119 s.

16. Elinç, H. (2011). Görsek Kalite Değerlendirmesi Yöntemi ile Antalya İli Alanya ilçesindeki Abdurrahman Alaeddinoğlu ve Alanya Belediye Başkanları Kent Parklarının İrdelenmesi. Y. Lisans Tezi, Selçuk Üniversitesi Fen Bilimleri Enstitüsü, Konya.

17. Gündüz, F. (1999). Turizmin Çevresel Etkilerinin Değerlendirilmesi ve Çevre Duyarlı Sürdürülebilir Turizm. Doktora Tezi, İstanbul Teknik Üniversitesi Fen Bilimleri Enstitüsü, İstanbul.

18. Gürlük, S. (2001). Dünyada ve Türkiye'de Kırsal Kalkınma Politikaları ve Sürdürülebilir Kalkınma, Uludağ üniversitesi İktisat Fakültesi Dergisi, 19 (4), 1-12.

19. Harris, J.M. (2000). Basic Principles of Sustainable Development. Global Development and Environment Institute Working Paper:00-04, Tufts University, USA.

20. Inskeep, E. (1991). Tourism planning: An integrated and sustainable development approach. New York: Van Nostrand Reinhold, 40 pages.

21. Karahan, F., Çil, A., Ercişli, S. (2017). Uzundere Biyolojik Çeşitlilik Stratejisi ve Eylem Planı (20172023). Erzurum, $191 \mathrm{~s}$.

22. Karahan, F., Kopar, I., Orhan, T., Çakır, E. (2011). The geopark potential of Tortum Valley (ErzurumTurkey) and its surroundings. In Natural environment and culture in the Mediterranean Region II , Newcastle: Cambridge Scholars Publishing, pp. 395-407.

23. Karakurt Tosun, E. (2013). Yaşam Kalitesi Ekseninde Şekillenen Alternatif Bir Kentsel Yaşam Modeli: Yavaş Kentleşme Hareketi. Uludă̆ Üniversitesi İktisadi ve İdari Bilimler Fakültesi Dergisi, 32 (1), 215237.

24. Karvonen, L. (2000). Guidelines for Landscape Ecological Planning. Forestry Publications of Metsahallitus. https://julkaisut.metsa.fi/assets/pdf/mt/mt36.pdf (27.11.2018)

25. Kaypak, Ş. (2011). Küreselleşme Sürecinde Sürdürülebilir Bir Kalkınma İçin Sürdürülebilir Bir Çevre. KMÜ Sosyal ve Ekonomik Araştırmalar Dergisi, 13 (20): 19-33.

26. Kopar, İ., Çakır, Ç. (2013). Determination of Geo-diversity of Lake Tortum-Tortum Gorge Valley and Surrounding Places (Uzundere-Erzurum and Yusufeli-Artvin) through Serrano and Ruiz-Flaño Method. I. Ü. Coğrafya Dergisi, 27, 46-66.

27. Kopar, İ., Sevindi, C. (2013). Tortum Gölü’nün (Uzundere-Erzurum) Güneybatısında Aktüel Sedimantasyon ve Siltasyona Bağlı Alan-Kıyı Çizgisi Değişimleri. Türk Coğ. Derg., 60, 49-66.

28. Korkut, A., Kiper, T., Üstün Topal, T. (2017). Kentsel Peyzaj Tasarımda Ekolojik Yaklaşımlar. Artium, $5(1), 14-26$.

29. Kozak, M.A., Bahçe, S. (2009). Özel İlgi Turizmi. Detay Yayıncılık, Ankara, 320 s.

30. Likert, R., Roslow, S., Murphy, G. (1934). A Simple and Reliable Method of Scoring The Thurstone Attitude Scales. The Journal of Social Psychology. Doi: 10.1080/00224545.1934.9919450

31. Miele, M. (2008). Cittaslow: Producing Slowness against the Fast Life. Space and Polity, 12, (1), $135-156$.

32. Özbey, R.F. (2002). Sustainable Tourism Development In Globalization Progress. Globalization and Sustainable Development, International Scientific Conference, Varna/Bulgaristan.

33. Özcan, A. (2017). Ekolojik Temele Dayalı Sürdürülebilir Kentsel Gelişme: Malatya Kent Örneği Üzerinden Bir Değerlendirme. http://www.ayk.gov.tr/wp-content/uploads/2015/01/\%C3\%96ZCANAy\%C5\%9Fe-EKOLOJ\%C4\%B0K-TEMELE-DAYALIS\%C3\%9CRD\%C3\%9CR\%C3\%9CLEB\%C4\%B0L\%C4\%B0R-KENTSEL-GEL\%C4\%B0\%C5\%9EMEMALATYA-KENT-\%C3\%96RNE\%C4\%9E\%C4\%B0-\%C3\%9CZER\%C4\%B0NDEN-B\%C4\%B0RDE\%C4\%9EERLEND\%C4\%B0RME.pdf (04.05.2018) 
34. Özdamar, K. (2003). Modern bilimsel araştırma yöntemleri. Kaan Kitabevi, Eskişehir, 344 s.

35. Özgeriş, M., Karahan, F. (2015). Rekreasyonel tesislerde görsel kalite değerlendirmesi üzerine bir araştırma: Tortum ve Uzundere (Erzurum) örneği. Artvin Çoruh Üniversitesi Orman Fakültesi Dergisi, 16 (1), 40-49.

36. Özgeriş, M. (2020). Sakin Şehir Uzundere'nin Planlama ve Tasarım Uygulamaları Yönünden Sürdürülebilirliğinin Değerlendirilmesi. Doktora Tezi, Atatürk Üniversitesi Fen Bilimleri Enstitüsü, Erzurum.

37. Özkök, F., Gümüş, F. (2009). Sürdürülebilir turizmde bilginin önemi. Yönetim Bilimleri Dergisi, 7(1), 5171.

38. Özmete, E. (2011). Sürdürülebilir Kalkınmanın Temel Prensipleri. Hacettepe Üni. Sosyolojik Araş. eDerg. http://www.sdergi.hacettepe.edu.tr/?page=makaleler (10.05.2020)

39. Page, S.J., Connell, J. (2006). Tourism: a modern synthesis. Thomson, London, 546 pages.

40. Shu-Yang, F., Freedman, B., Cote, R. (2004). Principles and Practice of Ecological Design. Environmental Reviews, 12, 97-112.

41. Şahin, İ., Kutlu, S. Z. (2014). Cittaslow: Sürdürülebilir Kalkınma Ekseninde Bir Değerlendirme. Journal of Tourism and Gastronomy Studies, 2 (1), 55-63.

42. Tıraş, H.H. (2012). Sürdürülebilir Kalkınma ve Çevre: Teorik Bir İnceleme. Kahramanmaraş Sütçü İmam Üniversitesi İktisadi ve İdari Bilimler Fakültesi Dergisi, 2 (2) , 57-73.

43. UN (1987). Report of the World Commission on Environment and Development: Our Common Future. http://www.un-documents.net/our-common-future.pdf (07.08.2018)

44. UN (1993). United Nations. Report of the UnitedNations Conference on Environment and Development. http://www.un.org/esa/dsd/agenda21/Agenda\%2021.pdf (09.08.2018)

45. UN (2015). Transforming Our World:The 2030 Agenda for Sustainable Development. https://www.un.org/ga/search/view_doc.asp?symbol=A/RES/70/1\&Lang=E (10.10.2018)

46. UNEP and WTO (2005). United Nations Environment Programme and World Tourism Organization. Making Tourism More Sustainable: A Guide for Policy Makers. http://www.unep.fr/shared/publications/pdf/dtix0592xpa-tourismpolicyen.pdf (01.08.2018)

47. URL-1 (2020). Cittaslow Türkiye. https://cittaslowturkiye.org/uyelik-sureci-ve-kriterler/ (28.10.2019)

48. URL-2 (2020). Cittaslow International. http://www.cittaslow.org/ (28.10.2019)

49. URL-3 (2018). BY Teknik Dizayn Proje. http://www.byteknik.com.tr/?p=866 (09.07.2018)

50. URL-4 (2018). $\quad$ Uzundere $\quad$ Belediyesi, Belediye http://www.uzundere.bel.tr/ihale_detay.asp?git=67 (10.11.2018).

51. UNWTO (2018). United Nations World Tourism Organization. Sustainable Development of Tourism. http://sdt.unwto.org/content/about-us-5 (01.08.2018)

52. WTO (2004). Indicators of Sustainable Development for Tourism Destinations: A Guidebook. Madrid, 507 pages.

53. Yazıcıŏ̆lu, Y., Erdoğan, S. (2004). Spss uygulamalı bilimsel araştırma yöntemleri. Detay Yayıncılık, Ankara, $448 \mathrm{~s}$. 